\title{
Learning curve and intraoperative cholangiography in prevention of iatrogenic injuries of the biliary tract
}

\section{Curva de aprendizado e colangiografia intraoperatória na prevenção de lesões iatrogênicas do tracto biliar}

Elton Carlos Leonardo Nogueira, Rodrigo Felipe da Silva Damasceno, luri Estrela Oliveira, Amália Cinthia Meneses Rêgo, Irami Araújo-Filho, Aldo Cunha Medeiros.

\footnotetext{
Performed at Department of Surgery, Federal University of Rio Grande do Norte (UFRN), Brazil, and Potiguar University, Natal, RN, Brazil.

Financial support: none.

Conflict of interest: none

Correspondence address: Irami Araújo Filho, Department of Surgery, Federal University of Rio Grande do Norte, at Av. Nilo Peçanha 620, Natal, RN, Brazil, Email: irami.filho@uol.com.br Submitted: 20 December 2013. Accepted, after review: 25 January 2014
}

\begin{abstract}
Cholecystectomy is the most commonly performed abdominal operation in the world. Laparoscopy is the standard procedure for performing this operation, and it have advantages over conventional surgery. However, a higher rate of iatrogenic lesions of the biliary tract is attributed to laparoscopy when compared to conventional cholecystectomy. Due to the importance of the topic, the purpose of this review was to analyze the factors involved in the largest number of lesions of the biliary tract observed during laparoscopic cholecystectomy compared to open surgery, and to evaluate the role of the learning curve and intraoperative cholangiography in the prevention of primary injuries of biliary tree.
\end{abstract}

Key words: Cholecystectomy, laparoscopy, Cholangiography, Biliary Tract, Injuries.

\section{RESUMO}

Colecistectomia é a cirurgia abdominal mais frequentemente realizada no mundo. A laparoscopia é o procedimento padrão para a realização desta operação, e tem vantagens sobre a cirurgia convencional. No entanto, uma taxa mais elevada de lesões iatrogênicas das vias biliares é atribuída à laparoscopia quando comparada à colecistectomia convencional. Devido à importância do tema, o objetivo desta revisão foi analisar os fatores envolvidos no maior número de lesões das vias biliares observadas durante a colecistectomia laparoscópica comparado à cirurgia aberta, e avaliar o papel da curva de aprendizado e colangiografia intra-operatória na prevenção de lesões primárias de árvore biliar.

Descritores: Colecistectomia, Laparoscopia, Colangiografia, Lesões biliares. 


\section{INTRODUCTION}

Laparoscopic cholecystectomy was introduced worldwide, and in Brazil it was firstly performed in 1990 in San Paulo ${ }^{1,2}$. Over time it became the gold standard in the management of benign gallbladder disease, symptomatic cholelithiasis and acute cholecystitis $^{1,3-6}$. The LC is associated with low morbidity, reduced hospital stay, low postoperative pain, early return to work and better cosmetic results when compared to open cholecystectomy ${ }^{1}$.

Despite the clear benefits of LC, the rate of bile duct injury rose from 0.1 to 0.2 $\%$ during the era of open cholecystectomy ${ }^{7-10}$ to $0.4 \%$ to $0.6 \%$ after the introduction of $\mathrm{LC}^{11-13}$. An incidence of $3 \%$ have been reported ${ }^{14-17}$. Of all the types of biliary trauma, iatrogenic injury during LC has been the most frequent ${ }^{1}$. Recent publication showed that incidence ofbiliary injuries are about $0.2 \%$ to $0.6 \%$, inversely proportional to the learning curve, but still remains high when compared to open cholecystectomy ${ }^{16}$.

Starting from the principle that laparoscopic cholecystectomy is considered the gold standard procedure in the treatment of cholelithiasis, the incidence of injury to the biliary tree should be low ${ }^{18}$. In agreement with the literature, it is believed that the lesions of the bile duct during laparoscopic cholecystectomy could be avoided through knowledge and understanding of the causes, risk factors, mechanisms, types of injuries and the practice of preventive measures during the laparoscopic procedure $^{19-21}$.

Therefore, the present study aimed to evaluate the role of the learning curve in laparoscopic cholecystectomy and the importance of intraoperative cholangiography in the prevention of primary biliary injuries.

\section{CLASSIFICATION OF BILLIARY TRACT INJURIES}

Several classification systems have been developed to describe anatomical lesions of bile ducts and help in treatment options. It is useful to classify biliary injuries for documentation purposes, as they help to establish prognosis after repair $^{22}$. Biliary injuries occurring during laparoscopic cholecystectomy tend to be more severe than those resulting from open cholecystectomy. The reasons for this are many, considering that the LC is performed in a retrograde manner (standard technique), then the level of injury can affect bile ducts of second and third order within the hepatic parenchyma ${ }^{23}$. Three main systems were developed to classify the injuries of the biliary tract (IBT): 
Table 1. Bismuth classification of biliary strictures

\section{TYPE CRITERIA}

I Stenosis at more than $2 \mathrm{~cm}$ from the confluence

II Stenosis at less than $2 \mathrm{~cm}$ from the confluence

III All the common hepatic duct without involvement of confluence

IV Complete or partial destruction of the confluence

V Injury to a right segmental branch, with or without involvement of the common hepatic duct

Adapted from Jarnangin WR, Blumgart LH. Benign biliary strictures. Surgery of the liver, biliary tract, and pancreas. Fourth Edition. 2007. P.634.

Table 2. Strasberg Classification.

A Leakage of the cystic duct or leakage of small ducts in the liver bed

B Occlusion of the right hepatic duct

C Transection without ligation of an aberrant right hepatic duct

D Lateral injury of common bile duct

E Bismuth Classification from E1-E5

E1 Stenosis at more than $2 \mathrm{~cm}$ from the confluence

E2 Stenosis at less than $2 \mathrm{~cm}$ from the confluence

E3 All the common hepatic duct without involvement of confluence

E4 Complete or partial destruction of the confluence

E5 Injury to a right segmental branch, with or without involvement of the common hepatic duct

Strassberg SM, et al . ${ }^{10}$ 
Table 3. Classification of laparoscopic bile duct injury.

Class Criteria

I Cystic duct confused with common bile duct, but recognized; incision extended from cystic duct to common bile duct, for cholangiography

II Lateral damage of the common hepatic duct by cauterization or clips, and bleeding associated with poor visibility.

III Common bile duct confused with cystic duct, or unrecognized; common bile duct, common hepatic, right hepatic or left hepatic transected or resected. cystic artery; sectioned right hepatic duct and right hepatic artery; lateral damage of right hepatic duct by cauterization or clips.

Way LW, et $\mathrm{al}^{26}$.

Despite the various classification systems developed to describe the lesions of bile ducts, none of them is free from any deficiencies ${ }^{1}$.

\section{CAUSES OF MAIN BILIARY TRACT INJURIES}

\section{ANATOMICAL VARIATIONS}

Although the mechanisms of bile duct injury during laparoscopic cholecystectomy are varied, the common denominator is the failure to recognize the anatomy of the triangle of Calot. This failure is attributed to anatomical risk factors, inadequate surgical technique or training ${ }^{24}$.

Anatomical distortions are the result of severe chronic or acute inflammation, morbid obesity bleeding and anatomical anomalies or variations ${ }^{25}$.

\section{IMPROPRIATE TECHNIQUE}

The bile duct injury during laparoscopic cholecystectomy results in most cases, the misinterpretation of the surgeon, errors of skill, knowledge or judgement ${ }^{26}$.

Inflammation in the triangle of Calot area can result in approximation of the cystic duct and common bile duct. Excessive retraction of the gallbladder body or insufficient lateral retraction of the infundibulum. This can align the cystic duct to the common bile duct. In these cases, the common bile duct may be confused with cystic duct, clamped and divided, resulting in its transection ${ }^{27-29}$. 


\section{LEARNING CURVE}

The inexperience of the surgeon with laparoscopic technique has been identified as an important cause of iatrogenic injury of bile ducts. This is the learning curve phenomenon that evolves previous operative experience at the level of open cholecystectomy ${ }^{30,31}$. The learning curve is defined as the number of repetitions required for the learner to develop skills and achieve proficiency, at which time the surgeon can perform the procedure without supervision ${ }^{32}$.

Surgical skill is acquired through hours of training, plus the knowledge of anatomy and operative technique, that enable surgeons to perform more complex operations $^{33}$.

Reviewing studies on laparoscopic cholecystectomy, it is observed that the point of proficiency average is around 30 procedures $^{34}$. However, there are studies where this number exceeds 200 cases $^{35}$. A review of more than 1.6 million LC showed an incidence of $0.5 \%$ biliary tract injuri, which did not decrease with increasing surgical experience ${ }^{11}$.

The Brazilian Society of Videosurgery established on 25 the minimum number of procedures for the surgeon to apply for the Certificate of Qualification ${ }^{36}$. The Brazilian College of Surgeons in association with the Brazilian College of Digestive Surgery and the Brazilian Society of Coloproctology, stablished various stages of the competition for obtaining the Certificate of Qualification, and required participation in theoretical and practical courses and proof of 15 videolaparoscopic surgeries ${ }^{37}$. Thus, two key elements are to gain experience in quality training and supervision ${ }^{38}$.

The proficient surgeon should be able to recognize the anatomical variations or dissect it safely despite the intense inflammatory process ${ }^{39}$.

\section{DIAGNOSIS OF INJURIES}

Most biliary injury during laparoscopic cholecystectomy are diagnosed to late. Patients complain of nonspecific symptoms such as vague abdominal pain, nausea, vomiting, low fever, usually resulting in leakage of bile into the peritoneal cavity. Some patients may develop sepsis from severe biliary peritonitis, jaundice or intraabdominal abscess ${ }^{40}$. Those who have early ligation or stenosis of bile ducts may present with jaundice and cholangitis. The median time to onset of symptoms was been two days ${ }^{41}$.

The bile duct injuries occur with sudden leakage of bile from the liver, soft tissue adjacent to the portal vein or persistent bilious drainage after section of the cystic duct. When there is doubt about the biliary anatomy, intra-operative cholangiography should be performed. In case of confirmed bile duct injury, referencing an experienced surgeon is the best decision ${ }^{42}$. 
An important step in assessing the bile duct injury is the identification of patency of vascular structures. Doppler ultrasonography should be performed to assess vascular integrity due to the fact that $12-32 \%$ of patients have concomitant arterial injury ${ }^{43}$.

The most commonly image exam performed for the diagnosis of bile duct injury is retrograde cholangiopancreatography $(E R C P)$ and magnetic cholangiography. ERCP can confirm the presence of biliary injury and provide a definitive management through temporary internal stent ${ }^{44}$.

\section{INTRAOPERATIVE CHOLANGIOGRAPHY}

There is evidence that the use of intraoperative cholangiography promotes a higher rate of identification of bile duct injury, reducing costs, length of stay and mortality ${ }^{45,46}$. Surgeons who are against cholangiography routinely emphasize that their adoption does not reduce the number of injuries and adds greater time and cost 47. All who are in favor, argue that their use does not prolong surgical time when performed by trained personnel ${ }^{48}$.

Thus, intraoperative cholangiography should be based on clinical and laboratory criteria or when the anatomy not seem clear intraoperatively, providing a lower cost/benefit ratio when used routinely ${ }^{49}$.

\section{MANAGEMENT OF INJURIES}

Additional tests should be requested to identify abdominal collections and determine if there is dilatation of the intrahepatic bile ducts. The final stage in the management of the bile duct injury includes defining the biliary anatomy and restoration of bilio-enteric communication. The extent of the injury determines the course of the operation ${ }^{50}$.

The best long-term results are obtained when the bile duct injury are recognized intraoperatively and repaired imediatamente. Estudies show that less than one third of iatrogenic lesions of the biliary tract are detected intraoperatively ${ }^{51.52}$.

Biliary injuries diagnosed postoperatively. Biliomas are treated by percutaneous drainage, and injuries by endoscopic stenting or Roux-en-Y reconstruction. The delayed repair is associated with poor outcomes (stenosis, narrowing) and high financial $\operatorname{cost}^{53}$.

In patients who underwent laparoscopic repair bile duct injury there was increase in morbidity and mortality. Patients who develop recurrent biliary strictures complain of chills followed by high fever. Pain in the right upper quadrant may or not be present. A high index of suspicion is necessary and initial episodes can be treated conservatively with antibiotics ${ }^{54,55}$. 


\section{PREVENTION}

As with any surgical procedure, prevention of complications through careful dissection and identification of the structures before transection is the best way for a favorable outcome. Whenever the anatomy of Calot's triangle can not be clearly defined, conversion to open surgery should be indicated ${ }^{56}$.

\section{FINAL THOUGHTS}

The bile duct injury is a delicate and fascinating subject where we should always aim prevention of injuries. We have confirmed through the data and studies that caution and knowledge of the anatomy are the best ways to prevent such injuries. These injuries may interfere in the patient live or in their quality, being considered by some the most malignant of benign injuries.

\section{REFERÊNCIAS}

1. McPartland KJ, Pomposelli JJ. Iatrogenic Biliary Injuries: Classification, Identification, and Management. Surg Clin N Am. 2008;88:1329-43.

2. Cezário Melo MA. Curva de aprendizado na videocirurgia. Rev Bras Videocirurgia. 2004;2:111-2.

3. The Southern Surgeons Club. A prospective analysis of 1518 laparoscopic cholecystectomies. N. Engl. J. Med. 1991;324:1073-8.

4. Dubois F, Berthelot G, Levard H. Laparoscopic cholecystectomy: historic perspective and personal experience. Surg Laparosc Endosc. 1991;1:52-7.

5. Schaefer M, Krahenbuhl L, Farhadi J, Buchler MW. Cholelithiasis-laparoscopy or laparotomy?. Ther Umsch. 1998;55:110-5.

6. Soper NJ, Stockmann PT, Dunnegan DL, Ashley SW. Laparoscopic cholecystectomy: the new 'gold standard'? Arch Surg. 1992;127: 917-23.

7. Flum DR, Cheadle A, Prela $C$ et al. Bile duct injury during cholecystectomy and survival in Medicare beneficiaries. JAMA. 2003;290:2168-73.

8. Andren-Sandberg A, Alinder G, Bengmark S. Accidental lesions of the common bile duct at cholecystectomy. Pre- and perioperative factors of importance. Ann Surg. 1985;201:328-32.

9. Roslyn JJ, Binns GS, Hughes EF, Saunders-Kirkwood K, Zinner MJ, Cates JA. Open cholecystectomy a contemporary analysis of 42,474 patients. Ann Surg. 1993;218:129-37. 
10. Strasberg SM, Hertl M, Soper NJ. An analysis of the problem of biliary injury during laparoscopic cholecystectomy. J Am Coll Surg. 1995;180:101-25.

11. Adamsen $\mathrm{S}$, Hansen $\mathrm{OH}$, Funch-Jensen $\mathrm{P}$ et al. Bile duct injury during laparoscopic cholecystectomy: a prospective nationwide series. J Am Coll Surg. 1997;184:571-8.

12. Ooi LL, Goh YC, Chew SP et al. Bile duct injuries during laparoscopic cholecystectomy: a collective experience of four teaching hospitals and results of repair. Aust N Z J Surg. 1999;69:844-6.

13. Waage A, Nilsson M. latrogenic bile duct injury: a population-based study of 152 776 cholecystectomies in the Swedish Inpatient Registry. Arch Surg. 2006;141:120713.Davids PH, Ringers J, Rauws EA, de Wit LT, Huibregtse K, van der Heyde MN et al. Bile duct injury after laparoscopic cholecystectomy: the value of endoscopic retrograde cholangiopancreatography. Gut. 1993; 34:1250.

14. Gigot J, Etienne J, Aerts R, Wibin E, Dallemagne B, Deweer F et al. The dramatic reality of biliary tract injury during laparoscopic cholecystectomy: an anonymous multicenter Belgian survey of 65 patients. Surg Endosc. 1997;11:1171.

15. Russell JC, Walsh SJ, Mattie AS, Lynch JT. Bile duct injuries, 1989-1993: a statewide experience. Connecticut Laparoscopic Cholecystectomy Registry. Arch. Surg. 1996;131:382-8.

16. Schlumpf R, Klotz HP, Wehrli H, Herzog U. A nation's experience in laparoscopic cholecystectomy: prospective multicenter analysis of 3722 cases. Surg Endosc. 1994;8:35-41.

17. Asbun JH, Rossi RL, Lowell JA, Munson L. Bile Duct Injury During Laparoscopic Cholecystectomy: Mechanism of Injury, Prevention, and Management. World J Surg. 1993;17:547-52.

18. Hunter JG. Avoidance of bile duct injury during laparoscopic cholecystectomy. Am J Surg. 1991;162:71-6.

19. Olsen DO, Asbun HJ, Reddick EJ, Spaw AT. Laparoscopic cholecystectomy for acute cholecystitis. Prob Gen Surg. 1991;8:426-31.

20. Reddick EJ, Olsen D, Spaw A et al. Safe performance of diflicult laparoscoPic cholecystectomies. Am J Surg. 1991;161:377-81.

21. Jarnagin WR, Blumgart LH. Benign biliary strictures. In: Blumgart LH, editor. Surgery of the liver, biliary tract, and pancreas. 4th edition. Philadelphia: Saunders; 2007. p. 628-54.

22. Bismuth $H$, Majno PE. Biliary strictures: classification based on the principles of surgical treatment. World J Surg. 2001;25:1241-4.

23. Csendes A, Navarrete $C$, Burdiles $P$ et al. Treatment of common bile duct injuries during laparoscopic cholecystectomy: endoscopic and surgical management. World J Surg. 2001; 25:1346-51.

24. Neuhaus $P$, Schmidt SC, Hintze RE et al. Classification and treatment of bile duct injuries after laparoscopic cholecystectomy. Chirurg. 2000;71:166-73.

25. Way LW, Stewart L, Gantert W et al. Causes and prevention of laparoscopic bile duct injuries: analysis of 252 cases from a human factors and cognitive psychology perspective. Ann Surg. 2003;237:460-9. 
26. Lau WY, Lai EC. Classification of iatrogenic bile duct injury. Hepatobiliary Pancreat Dis Int. 2007;6:459-63.

27. Alves $A$, Farges $O$, Nicolet $J$ et al. Incidence and consequence of an hepatic artery injury in patients with postcholecystectomy bile duct strictures. Ann Surg. 2003;238:93-6.

28. Stewart L, Robinson TN, Lee CM et al. Right hepatic artery injury associated with laparoscopic bile duct injury: incidence, mechanism, and consequences. J Gastrointest Surg. 2004; 8:523-30.

29. Sawaya DE Jr, Johnson LW, Sittig K, McDonald JC, Zibari GB. latrogenic and noniatrogenic extrahepatic biliary tract injuries: a multi-institutional review. The american surgeon. 2001;67:473-77.

30. Santos EG, Bravo Neto GP. Curva de aprendizado e lesões iatrogênicas em colecistectomias videolaparoscópicas. Rev Col Bras Cir. 2010;37:184-9.

31. Dagash $H$, Chowdhury M, Pierro A. When can I be proficient in laparoscopic surgery? A systematic review of the evidence. J Pediatr Surg. 2003;38:720-4.

32. Milcent M, Santos EG, Bravo Neto GP. Lesão iatrogênica da via biliar principal em colecistectomia videolaparoscópica. Rev Col Bras Cir. 2005; 32: 332-6.

33. Datta V, Chang A, Mackay S, Darzi A. The relationship between motion analysys and surgical technical assessments. Am J Surg. 2002;184:70-3.

34. Voitk AJ, Tsao SG, Ignatius S. The tail of learning curve for laparoscopic cholecystectomy. Am J Surg. 2001;182:250-3.

35. SOBRACIL. Disponível em: secretaria@sobracil.org.br. Acesso em 29 de setembro de 2010.

36. Colégio Brasileiro de Cirurgiões. Disponível em: http://www.cbc.org.br Acesso em 29 de setembro de 2010.

37. Windsor JA, Pong J. Laparoscopic biliary injury: more than a learning curve problem. Aust N Z J Surg. 1998;68:186-9.

38. Misawa T, Saito R, Shiba H, Son K, Futagawa Y, Nojiri T et al. Analysis of bile duct injuries (Stewart-Way classification) during laparoscopic cholecystectomy. J Hepatobiliary Pancreat Surg. 2006;13:427-34.

39. Aguiar GB, Oliveira CIB, Silva Júnior JBS, Santos LS, Vieira SC. Lesão iatrogênica de vias biliares. Rev Col Bras Cir. 2005;32:69-73.

40. Hobbs MS, Mai Q, Knuiman MW, Fletcher DR, Ridout SC. Surgeon experience and trends in intraoperative complications in laparoscopic cholecystectomy. $\mathrm{Br} \mathrm{J}$ Surg. 2006;93:844-53.

41. Ludwig K, Bernhardt J, Steffen $\mathrm{H}$ et al. Contribution of intraoperative cholangiography to incidence and outcome of common bile duct injuries during laparoscopic cholecystectomy. Surg Endosc. 2002;16:1098-104.

42. Strasberg SM. Biliary injury in laparoscopic surgery: part 2. Changing the culture of cholecystectomy. J Am Coll Surg. 2005;201:604-11.

43. Tantia $O$, Jain $M$, Khanna $S$ et al. latrogenic biliary injury: 13,305 cholecystectomies experienced by a single surgical team over more than 13 years. Surg Endosc. 2008;22:1077-86. 
44. Misra S, Melton GB, Geschwind JF et al. Percutaneous management of bile duct strictures and injuries associated with laparoscopic cholecystectomy: a decade of experience. J Am Coll Surg. 2004;198:218-26.

45. Al-Ghnaniem R, Benjamin IS. Long-term outcome of hepaticojejunostomy with routine access loop formation following iatrogenic bile duct injury. $\mathrm{Br} J$ Surg. 2002;89:1118-24.

46. Mercado MA, Chan $\mathrm{C}$, Orozco $\mathrm{H}$ et al. Prognostic implications of preserved bile duct confluence after iatrogenic injury. Hepatogastroenterology. 2005;52):40-4.

47. Walsh RM, Vogt DP, Ponsky JL et al. Management of failed biliary repairs for major bile duct injuries after laparoscopic cholecystectomy. J Am Coll Surg. 2004;199:192-7.

48. Nordin A, Halme L, Makisalo $\mathrm{H}$ et al. Management and outcome of major bile duct injuries after laparoscopic cholecystectomy: from therapeutic endoscopy to liver transplantation. Liver Transpl. 2002;8:1036-43.

49. Hugh TB. New strategies to prevent laparoscopic bile duct injury-surgeons can learn from pilots. Surgery. 2002;132:826-35.

50. Piacentini F, Perri S, Pietrangeli F, Nardi M Jr, Dalla Torre A, Nicita A et al. Intraoperative cholangiography during laparoscopic cholecystectomy: selective or routine? G Chir. 2003;24:123-8.

51. Reuver PR, Grossmann I, Busch OR et al. Referral pattern and timing of repair are risk factors for complications after reconstructive surgery for bile duct injury. Ann Surg. 2007;245:763-70.

52. Heise M, Schmidt SC, Adler A et al. Management of bile duct injuries following laparoscopic cholecystectomy. Zentralbl Chir. 2003;128:944-51.

53. Strasberg SM. Biliary injury in laparoscopic surgery: part 1. Processes used in determination of standard of care in misidentification injuries. J Am Coll Surg. 2005;201:598-603.

54. Topal B, Aerts R, Penninckx F. The outcome of major biliary tract injury with leakage in laparoscopic cholecystectomy. Surg Endosc. 1999;13:53-56.

55. Sicklick JK, Camp MS, Lillemoe KD et al. Surgical management of bile duct injuries sustained during laparoscopic cholecystectomy: perioperative results in 200 patients. Ann Surg. 2005;241:786-92. 